International Journal of Child, Youth and Family Studies (2016) 7(3/4): 381-403

DOI: http://dx.doi.org/10.18357/ijcyfs73-4201616091

\title{
STUDENTS’ PERCEPTIONS OF SCHOOLING: THE PATH TO ALTERNATE EDUCATION
}

\section{Liane C. Pereira and Jennifer Lavoie}

\begin{abstract}
Policies governing education in North America have given schools the responsibility of meeting the needs of a diverse student population, including those with emotional and behavioural difficulties (EBD). To balance their need for individualized programs with their right to inclusion in schools, students with EBD may be placed in alternate programs within a mainstream school setting. However, little is known about student experiences leading to this placement or their experiences in these programs. The purpose of this study was to explore youth's perceptions of the factors that influenced their being placed in an alternate program for students with EBD. Six eighth-grade students participated in semi-structured interviews and created a visual map of their school trajectories. An interpretative phenomenological analysis (IPA) of the data suggested that their schooling was a tumultuous journey that contributed to their emotional, behavioural, and academic struggles, and to their placement in an alternate school program. Students described disrupted school services, lack of supports, a negative school climate, and disengaging instructional strategies as contributing to their difficulties. An understanding of the influence of school context and policy on student behaviour is necessary if we are to improve educational outcomes and properly support child and adolescent development.
\end{abstract}

Keywords: alternate education, emotional and behavioural difficulties, EBD, interpretative phenomenological analysis

Liane C. Pereira, PhD (the corresponding author) is an assistant professor in the Department of Psychology, Central Washington University, Higher Education Center, Building 29, $2400 \mathrm{~S}$ 240 ${ }^{\text {th }}$, Des Moines, WA 98198. Email: lpereira@cwu.edu

Jennifer Lavoie, MEd is a doctoral candidate in the Human Development Program in the Educational and Counselling Psychology Department of McGill University, Education Building, 3700 McTavish Street, Montreal, QC H3A 1Y2. Email: jennifer.lavoie@mail.mcgill.ca 
School is a crucial component of children's and adolescents' social worlds, and is an important venue for the development of interpersonal skills, supportive peer and adult relationships, and positive self-perceptions (Nakkula \& Toshalis, 2006). Historically, students with disabilities or high needs have struggled to find the services they require. However, inclusion of all students into mainstream schools and classrooms is a strategy to promote healthy development, engagement, and overall success, and also a legal right. For students with particular emotional and behavioural needs, this right may be upheld through placement in alternate programs.

The British Columbia Ministry of Education (2013) characterizes students with serious behavioural and mental health difficulties as requiring co-ordinated inter-service/agency intervention and assessment processes to "manage, educate, and maintain the students in school and in their community" (Section E.5, p. 57). For students with such specialized needs, alternate programs have been found to be effective with regard to academic, disciplinary, and socioemotional outcomes (Cox, 1999; D’Angelo \& Zemanick, 2009; Haughey, 2009; Tobin \& Sprague, 2001; Vann, Schubert, \& Rogers, 2001; Wisner \& Norton, 2013). However, research tends to focus on individual factors over a narrow period to determine success. Such an approach cannot truly assess whether students are participating in a meaningful manner or achieving excellence in all aspects of schooling, nor can it capture the complexity of their experiences. This study examined students' perceptions of alternative education by engaging them in reflection on their school experiences as a whole and on factors that contributed to their educational placements.

\section{Students with Emotional and Behavioural Difficulties}

Emotional and behavioural difficulties (EBD) is an educational designation for students who have high emotional and behavioural needs that are often not adequately addressed in the regular classroom program (Quinn \& Poirier, 2004). The prevalence of EBD designations has been estimated at $1 \%$ of the overall student population (Lane, Wehby, \& Barton-Arwood, 2005; Olympia et al., 2004), with approximately 25\% of those designations being for girls (Trout, Nordness, Pierce, \& Epstein, 2003).

\section{Socioemotional Characteristics}

In general, students with EBD have been described as lacking in social competence skills (Cook et al., 2008; Desbiens \& Royer, 2003; Gresham, 2000), such as forming and maintaining friendships (Al-Hendawi, 2012). The designation of emotional disturbance, a subset of EBD, may in fact be determined "more on the basis of social-behavioral difficulties rather than 'emotional disturbances' ” (Cook et al., 2008, p. 131). Students in this category exhibit behavioural patterns that fall outside of societal norms (MacLure, Jones, Holmes, \& MacRae, 2012), and are labelled with EBD for problems that may in fact be socially rather than emotionally based. Indeed, EBD may be viewed as an understandable response to adverse life events and circumstances that is aggravated by systemic issues in the school environment. 
International Journal of Child, Youth and Family Studies (2016) 7(3/4): 381-403

Teachers and parents perceive these students as having more mental health challenges than their peers (Hackett et al., 2010); also, these students have a lower self-concept (Banks, Shevlin, \& McCoy, 2012). Overall, this suggests that issues with socioemotional development, and particularly the use of poor strategies for managing emotional responses and stress, are important factors in determining which students will be designated as having EBD.

\section{Behavioural Characteristics}

Students who are identified with EBD often have behaviour patterns that are not appropriate for the context (Erickson, Stage, \& Nelson, 2006), including violence, drug and alcohol use, disrespectful behaviour, skipping class, and fighting (D’Angelo \& Zemanick, 2009). Typically, a student with EBD will exhibit either externalizing behaviours that exist outside the individual, or internalizing behaviours that are directed toward the individual (Austin \& Sciarra, 2010). Externalizing behaviour is associated with oppositional tendencies and aggression, while internalizing behaviour is associated with depressive symptoms, anxiety, and isolation (Lane et al., 2005). These differences between the profiles of students with EBD can give guidance as to which services and supports should be provided for specific emotional and behavioural needs.

\section{Academic Characteristics}

Students with EBD often have concurrent academic difficulties. In general, they have lower overall academic achievement than their peers (Reid, Gonzalez, Nordness, Trout, \& Epstein, 2004; Trout et al., 2003). Students with EBD have also been associated with a higher likelihood of disengagement (Al-Hendawi, 2012) across cognitive, behavioural, and emotional domains (Janosz, Archambault, Morizot, \& Pagani, 2008; Linnenbrink \& Pintrich, 2003). Low levels of engagement have been shown to be one of the primary reasons for skipping classes (Fallis \& Opotow, 2003), and a significant predictor of high-school dropout (Christenson \& Thurlow, 2004). For example, students with EBD have roughly a 50\% probability of dropping out of high school (Aron \& Loprest, 2012; Kauffman \& Landrum, 2006), which is significantly higher than the general figure of about 30\%, as represented by the United States' 2010 class (Snyder \& Dillow, 2010). Indeed, students with EBD have higher dropout rates compared to students with other types of special educational designations (Christenson, Sinclair, Lehr, \& Godber, 2001; Kauffman, 2001). Given that dropout can best be understood as a process that occurs over time (Christenson et al., 2001; Rumberger, 2011), it is important to offer support to students before they become disengaged and develop a higher likelihood of dropping out.

\section{Transitioning to High School}

Adolescence is a time of rapid physical, social, and emotional change. Milestone events, such as the transition to a new educational setting, can cause turmoil and confusion as students negotiate a new environment with new courses, teachers, friends, peer groups, and social norms. This time of transition is important: students who struggle with such a change have a higher likelihood of dropping out (Cohen \& Smerdon, 2009; Curran Neild, Stoner-Eby, \& Furstenberg, 2008). 
International Journal of Child, Youth and Family Studies (2016) 7(3/4): 381-403

For students with EBD, the transition is especially difficult because they already struggle with their emotional responses and behavioural patterns, and may not have developed adequate social skills to navigate the transition (Cook et al., 2008). They may also struggle with diagnosed or undiagnosed mental health problems (Hackett et al., 2010). In either case, they have particular needs that must be addressed by the practices and curricula of the school environment.

Determining how well alternate programs are meeting students' needs is important for their current and future education.

\section{EBD and Alternate Education}

The terms "alternative” and "alternate” are used interchangeably to describe a wide range of specialized school programs that offer courses, curriculum, and instructional strategies not generally found in traditional mainstream settings (De La Ossa, 2005). Alternate school programs exist within the school system as a means of providing students who have specific needs with adaptations and accommodations (Lehr, Tan, \& Ysseldyke, 2009; Mottaz, 2002). In particular, alternate programs generally provide additional support for social, emotional, and academic needs associated with positive development (Farkas et al., 2012), while maintaining students' meaningful participation in the social activities of schooling.

The hope is that placing students with EBD in these alternative programs with fewer students and more intensive support and flexibility has benefits across domains that counter the social detriments of a more restrictive environment. In some instances, this is the case. For example, students with EBD who are enrolled in these programs have better grades, attendance, and self-esteem, and fewer behavioural issues (Cox, 1999; D’Angelo \& Zemanick, 2009; Haughey, 2009) relative to students with EBD in traditional school programs. Although research has focused on individual factors such as absenteeism or lack of engagement (Joe, Joe, \& Rowley, 2009), substance use (Morone, Kilbreth, \& Langwell, 2001; Ross \& Wu, 1995), and poor mental health (Oeseburg, Jansen, Dijkstra, Groothoff, \& Reijneveld, 2010), this approach fails to capture the broad, complex, and multi-systemic factors that impact students with EBD.

Creating a space for students' voices about their specialized needs is of paramount importance for ensuring educational success (Cook-Sather, 2006; Fielding, 2001; Levin, 2000; Mitra, 2003), especially in alternate educational settings. Indeed, research suggests that there is a disconnect in alternate programs between the needs that students perceive they have and the services that they receive (Merrell \& Walker, 2004; Streeter, Franklin, Kim, \& Tripodi, 2011); unfortunately, relatively few studies provide a detailed account of students' perceptions (Clarke, Boorman, \& Nind, 2011; De la Ossa, 2005; Phillips, 2013; Watson, 2011). Understanding students' experiences is vital because students who have negative school experiences have higher numbers of vulnerabilities as adults, including less education, limited or poor perceived future work life, and less general success (Andersson \& Strander, 2004).

Determining students' needs, and the effectiveness of support strategies, is clearly necessary, but should involve the key people involved in student success - the students 
International Journal of Child, Youth and Family Studies (2016) 7(3/4): 381-403

themselves (Cook-Sather, 2006; De La Ossa, 2005; Phillips, 2013). This is an important step towards identifying practices and policies that shape their educational experiences, and consequently their educational outcomes.

\section{Significance of the Study}

The connection between education and well-being is important for understanding the impact of educational practices and policies on schools' abilities to meet their mandated objectives (Fantuzzo, McWayne, \& Bulotsky, 2003; Knis-Matthews, Bokara, DeMeo, Lepore, \& Mavus, 2007). Many students with EBD are removed from mainstream school settings (Calhoun \& Daniels, 2008), and may only return to school when a different educational setting becomes available (Carroll, 2008). However, students may not have been consulted at any stage of the process or asked about how they can be supported in school. This qualitative study invited students to freely express their perspectives on their schooling, including the transition from traditional school settings to a remedial-focused alternate program.

Specifically, the emphasis of this phenomenological study is to understand and describe the educational experiences of adolescents enrolled in alternate programs in a large school district in western Canada. The focus is to explore eighth-grade students' lived educational experiences, from kindergarten through their current alternate school program, and uncover their sense of being a student while also contending with educational, emotional, or behavioural concerns that probably contributed to their placement in an alternate program.

\section{Method}

Phenomenology aims to capture the essence of human experiences, based on the perspectives of those living through the phenomenon and those researching it (Moustakas, 1994), primarily through interpretation of participants' constructed meanings. A phenomenological approach highlights the views of the participants without preconceived notions of how they experience the phenomenon or what those experiences mean to them; instead, understanding comes from an impartial, co-operative relationship between the participants and the researcher (Haggman-Laitila, 1999). As the students themselves are the most significant stakeholders in their learning and well-being, their constructed meanings and experiences, both positive and negative, are vital sources of information to communicate to educators, administrators, and policy makers.

Interpretative phenomenological analysis (IPA) was chosen as the specific method of analysis for this study. IPA is concerned with exploring the lived experiences of individuals, but it goes more deeply into those experiences by trying to discern their significance as they occur in daily life (Smith, Flowers, \& Larkin, 2009). Although the recollected details of any experience may become disjointed across time, they will still have a common meaning and significance to the individual. This continuity of meaning fosters reflection, thinking, and feeling as the 
International Journal of Child, Youth and Family Studies (2016) 7(3/4): 381-403

individual processes the composite of the moments or details that he or she has unified as his or her experience (Smith, 1996; Smith \& Osborne, 2003).

\section{Study Objectives}

This study aimed to: (a) understand the past and present lived educational experiences of students who have been placed in alternate programs, (b) examine these experiences from a Canadian perspective, (c) focus solely on student experiences and perceptions of schooling, and (d) situate those experiences and perceptions within a systemic developmental framework. All procedures were approved by the ethics board of the academic institute of the primary investigator and the target school district.

\section{Target Alternate Program}

The recruitment sites were remediation-focused alternate programs in the target school district. These programs were located on traditional secondary school sites, and provided academic support to up to 12 students, ages 13 to 16, who had not been successful in regular classroom settings. The intended duration of the programs ranged from one semester to three years; at 16, or upon completion of Grade 10, students were expected to transition to mainstream programs.

The programs offered an adapted curriculum, reduced or flexible schedules, and selfpaced coursework, while also allowing students to participate in some regular classes. Students had access to the staff and services at the main school (e.g., administrators, counsellors, career and employment guidance, and extra-curricular activities).

\section{Participants}

Smith et al. (2009) recommend three to six participants in IPA to best capture the nuances that influence participants' experiences. All students from three programs were invited to participate in this study. A final sample of six students, ages 13 and 14, who were enrolled for at least 30 days, and began secondary school in the target alternate program, was recruited for this study; all of the participating students came from two of the programs.

Participants included two boys and four girls who were enrolled in Grade 8; two students were repeating the grade. Two students were living with two parent-figures, whereas three were living with only their mother, and one was living with grandparents. All participants described living in comfortable homes in secure neighbourhoods, though two also mentioned inadequate food and clothing resources. Two students self-identified as minorities, two as Caucasian, and two did not include this in their descriptions; school reports described them as Caucasian.

\section{Data Collection}

Three data collection methods were selected based on three criteria: their suitability within a phenomenological perspective, the needs of the targeted participants, and the necessity 
International Journal of Child, Youth and Family Studies (2016) 7(3/4): 381-403

for managing researcher bias. The methods chosen were visual data/mapping, semi-structured interviews, and field notes and participant observations.

Visual data/mapping. As Prosser (2011) stated, visual data are used in qualitative studies to gather a broad range of participant responses about a particular phenomenon. This method recognizes the struggles that participants might have with writing and speaking tasks. It is a creative approach that provides participants with multiple means of expressing themselves, generating rich data while preparing students to engage in the interview (Hall, Meyer, \& Rose, 2012).

Semi-structured interviews. Interviews lend themselves well to qualitative studies and are often employed in phenomenology (Lincoln \& Guba, 1985), as they can help to develop a fuller perspective on the thoughts and feelings associated with events. Interviews consisted of four open-ended questions that increased in specificity and sensitivity (Kvale, 2007). The primary researcher allowed participants to lead the interview and focus on their most meaningful experiences (Biggerstaff \& Thompson, 2008), while both parties asked questions and offered comments (Haggman-Laitila, 1999). This type of interview is crucial to the interpretative process of IPA and the management of researcher bias (McConnell-Henry, Chapman, \& Francis, 2011).

Field notes and participant observations. The principal researcher made several site visits outside of recruitment and data collection times to help her understand the participants' school environment. This preparation is important for IPA because it focuses on a specific group in a particular context. During all site visits, the principal researcher kept field notes of general and participant observations. These included descriptions of the school and alternate program location, the physical space and classroom organization, and the policies and practices observed in each classroom.

\section{Procedures}

Each participant attended two or three sessions of varying length, depending on the participant's verbal expressiveness and schedule. In the first session, participants completed a map of their school journey, representing their past and present educational experiences. In subsequent sessions, the participants answered open-ended questions about schooling and student life.

The first session began with snacks, re-introductions, and a review of the study, recording procedures, and informed consent; participants were also asked to select a pseudonym to be used in all communication. Next, the school journey map was described and completed. Specifically, participants were asked to draw a representation of the school path they had taken including the target alternate school program. They were encouraged to highlight all the key places, events, people, ideas, and feelings that were most important to them. Sessions were recorded as participants described their maps and answered clarifying questions. This took approximately 45 to 90 minutes. 
International Journal of Child, Youth and Family Studies (2016) 7(3/4): 381-403

In subsequent sessions, the primary researcher conducted the semi-structured interviews. Each participant answered four open-ended questions, as well as more general introductory questions. Sessions ended with a summary, a general inquiry about any further comments (Patton, 2002), and a reminder about confidentiality. This took approximately 35 to 75 minutes.

\section{Data Analysis}

Thematic analysis is a fundamental and flexible method of approaching qualitative data and offers guidelines to answering research questions through deliberate and thoughtful analysis (Braun \& Clarke, 2006). The researcher first familiarized herself with the transcribed interviews, reading and re-reading the text for accuracy and initial ideas. This led to initial codes and identifying specific data points that were relevant to each code. The codes were grouped into themes and, again, data relevant to each theme were collected. The themes were reviewed to see if they worked with the initial coded extracts and data set as a whole.

The IPA paid particular attention to language in an iterative and inductive process that drew meaning from particular experiential materials (Smith et al., 2009). It involved line-by-line analysis of text to identify the relationships among emerging themes in the context of the participant's world and the researcher's psychological knowledge. The stages of IPA suggested by Smith et al. (2009) that guided this study included multiple readings, initial noting, developing emergent themes, connecting emerging themes, and looking for patterns across cases.

\section{Results}

Overall, there were some commonalities among the participants' descriptions of themselves. Though many commented briefly on difficulties with in-school concentration or attendance, all participants viewed any academic struggles as temporary and not reflective of their abilities. One major theme identified in capturing participants' school experiences and their path to an alternate program focused on the instability and insecurity of their schooling.

\section{Primary Theme: Schooling as Tumultuous}

The participants described the path of their schooling as disordered and inconsistent. Although their recollections were fragmented, they reported clear memories of struggles with upheavals caused by multiple school and staff changes. The untimely school transitions compounded the strain of negotiating the natural changes in schools that are experienced by all students. For these students with emotional and behavioural difficulties, the lack of structure and stability was problematic. When students did manage to anchor themselves in a particular school, they were averse to its climate, which they perceived to be competitive, and rife with inflexible policies and practices.

Disruptive school experiences. Schools can provide stimulation, stability, and support, as well as an education for children. These participants, however, described their school journeys as forgettable, disjointed, and unpredictable. 
International Journal of Child, Youth and Family Studies (2016) 7(3/4): 381-403

First, most of the participants had very few memories of early elementary school. Payton, Aurora, and Cole could not remember the names of their schools or many details of their experiences. Cole later tried to trace his school path:

I think I was there for Grade 1. And then in Grade 2 I went [Pause] no [Pause] I went to [School] for kindergarten and Grade 2. And then maybe I went to [School] for Grade 1.... And then in Grade 3 I went to [School].... I don’t know [Sigh].

Participants' memories became stronger regarding Grade 3 onward, but in general were negative. With each transition came new teachers, principals, classmates, environments, and rules — and participants scrambled to adjust. Aurora said, "Sometimes I feel like I had to freaking redo a bunch of classes that I shouldn't have had to do, or grades that I shouldn't have to do ... everybody was so immature. I felt like I was going back in time.” Payton once transferred mid-semester and commented, "I was really far behind.... But I catched up on science a little bit and I'm retaking my test. I'm doing my work sheet, so just to get my grades up.” For students who were already having difficulty with the academic and social demands of schooling, multiple transitions only aggravated the strain.

Social changes, as well as the transition to a new institution, proved difficult for these students. Logan described her difficulties in finding friends after changing schools, "I went into the new school in Grade 6. But I still didn’t really make friends for a year.” For Cole, the social aspects of school were particularly stressful and taxing. He found talking to adults and making connections with peers very difficult, yet wanted to be around people. His most detailed memory was of transferring mid-semester and arriving midway through a class. He expressed appreciation for the social graces of his teachers and classmates in a detailed account of one moment in his school journey. And those small social gestures gave him lasting friendships and stability in his school life, easing the disruption of his school changes.

The disarray of participants' school journeys was exacerbated by their absences due to suspensions, stress, or avoidance. All of the participants except Damien had been suspended, and Logan described being frustrated during a longer suspension:

I wasn't allowed to go to school for a week. And my friend [Name] ... she just gave me my homework every day. Half the time, I'd be like ... I really didn’t want to get behind in my homework. So I'd be on the computer, researching what we were doing.... Or I'd be just sitting there.

She noted a pattern when school was discouraging of "not really acting the same. I get [Pause] I give attitude to teachers. And then I get sent to the office. And then I get suspended. And I end up skipping. And it's not that great.”

Indeed, for most of these students, the culmination of this disruptive experience was expulsion, leading directly to their placement in an alternate program. Payton was suspended for 
International Journal of Child, Youth and Family Studies (2016) 7(3/4): 381-403

"half the month" after a physical altercation, and was eventually expelled and forced to transfer schools. Aurora, too, was expelled, reporting that she was so disheartened by on-going bullying that she "punch[ed] the next person who bullied" her. Not only did students feel the injustice of being expelled for "self-defense" after their pleas for support were ignored, but they were also excluded from any opportunities to learn. Ariel's wait was much longer:

And they just kicked me out and told me I wasn't going to go back.... And there wasn't a [alternate program] for a bit. And then I just got kicked out of school [Pause] I don't know. No one helped me. I did nothing for two months.

In these participants' school journeys, academics were already a challenge before the lengthy gaps in instruction due to absences, suspensions, and expulsions. This is not to say that students were rejecting school. Five participants mentioned a particular school as a safe haven this was the anchor and shelter of their school journey that meant all the more to them because the rest of their experience was so tumultuous.

Responding to the ecology of schools. It may seem that students with social, emotional, and behavioural issues simply lose interest in school. For these participants, their lack of compliance, task completion, and attendance was not disengagement, but a response to an institutional system they found inimical. As students, they were dynamic parts of the complex, diverse, and competitive "ecology" in which they learned and developed. Their processing of their position within this system, however, resulted in behaviours that challenged and resisted the very nature of schools.

Rejecting the school environment. Payton exclaimed about one school, “That school shouldn't even be a school. It should be a private school, the way they treat children there.... I mean, if that was the last school on earth I wouldn't [go there] ... and I care about my grades.” Participants' rejection of schools seemed to be based on an impression built in part from the appearance or reputation of the school. For example, Ariel asserted about one school, "I never wanted to go to that school. Even in elementary school I knew that was a bad school.” Ariel rejected another school because it looked like a "classy" school rather than a "creative school [where] kids had fun... not just gray and blue and green.” Similarly, Aurora talked about her initial reaction to seeing one school:

I felt like I was in a dungeon. Bars on the windows. I'd be like, I don't like this window. Because our classroom windows were just plain, you know... Had bars on them ... I never will like that school, ever.

Those first perceptions of certain schools were powerful and enduring, and shaped the participants' interactions within these imposing environments.

Struggling to learn and engage. Students not only opposed the physical spaces but also the stifling nature of traditional models of education. Some participants refused to attend or 
comply because they felt they were not being respected. Aurora, Ariel, and Payton would skip the classes with rules or teaching practices they did not like. They had difficulty with the pace of instruction, especially when they transitioned to secondary school where, according to Ariel, teachers did not help as much "because they're worrying about a bunch of other stuff." She explained the difference:

The teachers just didn't teach me properly. And I didn't like going there because I didn't understand it and because the teachers suck at teaching.... The elementary teachers, they like take it slow and make sure you understand it. The teachers don't even explain it to you in high school.... And I ask for help so much times. I embarrass myself in front of the whole class just to figure out what I need help with and stuff.

This difference definitely impacted Ariel's success: "High school was way harder for me to learn things. That's why I failed like three classes. [In] elementary, I never failed anything." Aurora further described the demands of secondary school, "Yesterday we had a review package that we had to finish that day. And then today we have our test. That's not enough time for some kids to, you know, actually pick up the learning and soak it into their brains.”

For Aurora the fast pace was even more daunting given the strategies and styles of teachers. She wanted differentiated instruction rather than just, "talking, and talking, and talking [without] anything on the board or anything to show visual learning ... they're just like, one voice. They don’t like form actions or anything.” Aurora wanted engaging and varied instructional styles and a meaningful curriculum:

It's getting boring. Like, I honestly feel like with science and stuff that I'm just learning the same crap over, and over, and over again.... Like the body system. I feel like, okay, I learned that in Grade 6, 7, 8. I don’t know, I’ll probably learn more in 9, 10, and 11.

Cole stressed the importance of "good" teaching and extra help from his high school Math teacher. Aurora also described her French teacher who "stood out" as positive because she “actually taught us stuff. Taught us tricks how to remember things.” Participants also commented on the importance of story-telling and personality in teachers. As Damien said, a good teacher "puts a lot of personality into what he does and whatnot. I like that. Like he's teaching from the heart.” For these participants, the appropriate teaching style and efforts to support student learning could ease the academic demands of secondary school.

Coping with competition. Participants also questioned the climate of competition and pressure to perform. As Payton explained, "It's more like, you have to be good and you have to be perfect to be at school.” Ariel agreed, “Like, kids are always pressured to be like perfect, you know. And that's why a lot of kids are like sad these days, because they're always pressured to be like perfect." But as expectations rise and students attempt to meet them, they become overwhelmed. Aurora became agitated as she described the pressure to earn certain grades: 
International Journal of Child, Youth and Family Studies (2016) 7(3/4): 381-403

Having to study so much for those little tests that have so much of your mark, help you pass, it's stressful. Because I mean, you know, you want to get a good grade. You want to pass school. You don't want to have to repeat a grade. So you're just having to focus and focus, and focus, and focus. And you have other things on your mind [Sigh].

Logan also described this experience:

It's just like the pressure of all the homework, or the pressure of all ... You want to impress the teacher, so you try to do good. But as you're trying to do good, you're kind of not really doing that great because it's just like you're worrying about impressing people. But at the same time, you're kind of failing at it.

Repeatedly, these participants stressed their motivation to do well and their understanding of the relationship between school and future success, but they also stressed the need to escape the unremitting academic burdens of school. Unfortunately, for most participants this ability to escape was lacking in their later school experiences. Damien suggested that there is "more freedom [and] they allow you to walk in the halls and whatnot," but he was frustrated that his primary means of relaxing, playing video games, was restricted. For Cole, playing sports at lunch was to socialize and "get out aggression" while Aurora and Logan used creative arts like drawing, playing music, and singing to escape from the stress of school. Still, this was not quite enough for Aurora: “God, I so miss recess. I miss having twice a day where you could just go outside and not worry about school. Now it’s just once a day.”

\section{Discussion}

These participants described schooling as a stressful and disorderly social process that required a significant amount of energy, and demanded their full complement of coping strategies. They stressed that these factors played integral roles in their lack of school success in more traditional settings. These results suggest that students with EBD could better navigate school if their subjective experiences were used to inform practices and policies.

\section{Maintaining School Services}

Participants described having disjointed school journeys that started in primary school, and needing multiple supports for issues in academic, social, emotional, and behavioural areas. However, for students with individualized educational needs, schooling can be marked by numerous shifts and breaks. Multiple in-class and outside settings (Gregory \& Cornell, 2009), working with several different adults (Gregory \& Weinstein, 2008), or experiencing a number of school and program transfers, may deprive students of the stability needed to create a sense of community. This is especially problematic for students with EBD who work best with consistent expectations and supports (Kauffman, 2001), and who may withdraw when school becomes difficult. In fact, without appropriate support, such students will withdraw from learning (Osler, 2006). This self-exclusion may not be a purely individual factor related to student 
International Journal of Child, Youth and Family Studies (2016) 7(3/4): 381-403

maladjustment, but a reaction to environments that disregard rather than recognize "the mundane tyrannies of everyday exclusion - the student who is 'crying, worrying, refusing to do her schoolwork' " (Osler, 2006, p. 578). To promote positive development among students with EBD, schools need to provide stability and structure as much as possible.

Disciplinary practices also contributed to school exclusion, particularly when interim services were not provided. The target programs all had zero-tolerance policies aimed at reducing school violence and drug-related offences and thereby increasing student safety (Skiba, 2002; Skiba \& Knesting, 2001). However, the use of these policies has been controversial (Dinkes, Cataldi, Kena, Baum, \& Snyder, 2006; Fenning et al., 2012) for resulting in school exclusion, with the excluded youth often coming from disadvantaged backgrounds (Bear, 2012; Carroll, 2008). Indeed, participants' aggressions did not involve weapons or drugs, yet they were suspended or expelled with no interim services, as has been reported in other studies (Pirrie et al., 2009; Pirrie, Macleod, Cullen, \& McCluskey, 2011). Throughout their schooling, these participants were suspended for fighting, and four were ultimately expelled pending placement in an alternate program, despite being deemed safe enough to return to a mainstream school setting. The adherence to strict disciplinary policies did not appear to be primarily due to safety concerns, and undermined students’ right to education.

Exclusion imposed with little flexibility maintains unwanted behaviours, and fails to teach more desirable behaviours or to help the student recognize contributing factors (Black, 2004; Hemphill, Plenty, Herrenkohl, Toumbourou, \& Catalano, 2014; Kohn, 2004; Osler, 2006; Skiba, 2002). Furthermore, suspensions have led to lengthy absences with the onus on the family to find accommodations (Carroll, 2008; Pirrie et al., 2009; Skiba \& Knesting, 2001). Consistent with this research, these participants were excluded from the disciplinary and educational decisions that impacted them, and the reasons underlying their behaviours were not considered or were given little weight. A multi-level perspective of student behaviours could help to inform disciplinary practices and to avoid unnecessary exclusions while teaching students more positive behaviours and interpersonal skills.

\section{Addressing the School Environment}

Participants' educational performance was negatively impacted due to a mismatch between student needs and teaching strategies. Participants experienced schooling as meaningless and disengaging as they struggled to meet the expectations of multiple educators across multiple settings. Consistent with the literature, participants emphasized that the key to adjusting to these changes was a supportive and consistent peer group (Pirrie et al., 2009), within a positive environment.

School climate refers to the safety, discipline, fairness, warmth, and support of the social and physical environment (Fan, Williams, \& Corkin, 2011). Indeed, school climate has been associated with academic achievement, motivation, and performance (Battistich, Solomon, Kim, Watson, \& Schaps, 1995; Griffith, 1999; Roeser \& Eccles, 1998; Stewart, 2007), and sense of 
school belonging (Vieno, Perkins, Smith, \& Santinello, 2005). School climate has also been associated with psychosocial factors such as well-being and adjustment (Brand, Felner, Shim, Seitsinger, \& Dumas, 2003; Kuperminc, Leadbeater, \& Blatt, 2001), and prosocial behaviour (Coker \& Borders, 2001). When students struggle socially or academically, physical and creative outlets are needed to alleviate stress. When school policies or disciplinary practices deny students these opportunities, they also deny students positive means of coping with stress. In sum, students' learning and experiences are shaped through their perceptions of their environment (Bandura, 2001), and students need positive school settings that provide the physical, emotional, and intellectual safety required to learn and succeed.

Simply monitoring students does not create a positive school climate (Bear, 2012), nor does it take into account the impact of such practices on students (Kohn, 2004). Often, student voices have not been heard despite students being "able to make a valid and essential contribution to understanding of processes and systems of discipline in school” (McCluskey, 2014, p. 94). Students reported that adults do not care about, listen to, support, nor respect students (Cornell \& Gregory, 2008). Furthermore, when rules were deemed unfair or unclear, the number of problems related to school order, safety, and discipline increased (Fan et al., 2011). Kohn (2004) argued that "we should ask not have we done enough to stamp out this behaviour but how can we transform schools into places that meet students' needs so that students don't lash out in fury" (p. 38). The interactions between individuals, their environments, and the systemic and sociocultural school factors contributing to and maintaining behaviours should be considered in exploring the experiences of students with EBD.

\section{Limitations}

In phenomenological studies, generalization is not the purpose; the nature of an interpretative analysis is subjective, and the reader must take into account the subjective stance of the researcher, the description of the participants, and the context of the study to determine whether the findings are pertinent to their research and applications.

The demographic profiles of the participants sample warrant further discussion. There were more females than males included in this study, which differed from the program demographics of approximately two-thirds males. Rapport with a female researcher or the nature of the study requiring verbal and creative expressions of personal information may have influenced the responses and analysis. Similarly, the final sample represented only two of five programs. The ways in which the unique perspectives of the students from other programs, based on their experiences in different school environments, would have contributed to the findings is unknown. Again, the specific nature of IPA, and the small sample, limits the transferability of the findings to other groups and contexts, but the ideas and questions raised can inform further analyses of youth's schooling experiences. 
International Journal of Child, Youth and Family Studies (2016) 7(3/4): 381-403

\section{Future Directions}

Students with EBD are entitled to an education commensurate with that of their peers, but achieving this requires a thoughtful approach to education. Creating safe and positive school climates to foster positive teacher-student and peer relationships should be given high priority in promoting learning and development. Students' emotional and behavioural struggles may be warranted reactions to hostile interactions and toxic environments, and could be mitigated by systemic changes.

Just as dropping out is not an event that occurs at a specific moment, but rather the conclusion of a process that includes gradual disengagement (Rumberger, 2011), placement in an alternate program is the result of years of struggles in traditional school settings. In taking a broader ecological perspective of student experiences, the temporal components must be considered. To inform policies and practices that positively impact development, interventions should target the early stages of EBD, which requires routine examination of school trajectories, not waiting until difficulties become severe and students are excluded from school. Furthermore, rather than focusing on the individual, preventative and early intervention strategies should be implemented at the broader school and district levels. Practitioners and researchers alike must consider the multi-faceted and multi-level nature of schooling in their consideration of how to best serve students in the least restrictive manner. 
International Journal of Child, Youth and Family Studies (2016) 7(3/4): 381-403

\section{References}

Al-Hendawi, M. (2012). Academic engagement of students with emotional and behavioral disorders: Existing research, issues, and future directions. Emotional and Behavioural Difficulties, 17(2), 125-141. doi:10.1080/13632752.2012.672861

Andersson, B.-E., \& Strander, K. (2004). Perceptions of school and future adjustment to life: A longitudinal study between the ages of 18 and 25. Scandinavian Journal of Educational Research, 48(5), 459-476. doi:10.1080/003138042000272122

Aron, L., \& Loprest, P. (2012). Disability and the education system. The Future of Children, 22(1), 97-122.

Austin, V. L., \& Sciarra, D. T. (2010). Children and adolescents with emotional and behavioral disorders. Boston, MA: Merrill.

Bandura, A. (2001). Social cognitive theory: An agentic perspective. Annual Review of Psychology, 52, 1-26.

Banks, J., Shevlin, M., \& McCoy, S. (2012). Disproportionality in special education: Identifying children with emotional behavioural difficulties in Irish primary schools. European Journal of Special Needs Education, 27(2), 219-235. doi:10.1080/08856257.2012.669111

Battistich, V., Solomon, D., Kim, D.-i., Watson, M., \& Schaps, E. (1995). Schools as communities, poverty levels of student populations, and students' attitudes, motives, and performance: A multilevel analysis. American Educational Research Journal, 32(3), 627658.

Bear, G. G. (2012). Both suspension and alternatives work, depending on one's aim. Journal of School Violence, 11(2), 174-186. doi:10.1080/15388220.2012.652914

Biggerstaff, D., \& Thompson, A. R. (2008). Interpretative phenomenological analysis (IPA): A qualitative methodology of choice in healthcare research. Qualitative Research in Psychology, 5(3), 214-224. doi:10.1080/14780880802314304

Black, S. (2004). Beyond zero tolerance. American School Board Journal, 191(9), 62-64.

Brand, S., Felner, R., Shim, M., Seitsinger, A., \& Dumas, T. (2003). Middle school improvement and reform: Development and validation of a school-level assessment of climate, cultural pluralism, and school safety. Journal of Educational Psychology, 95(3), 570-588.

Braun, V., \& Clarke, V. (2006). Using thematic analysis in psychology. Qualitative Research in Psychology, 3(2), 77-101. doi:10.1191/1478088706qp063oa 
International Journal of Child, Youth and Family Studies (2016) 7(3/4): 381-403

British Columbia Ministry of Education. (2013). Special Education Services: A Manual of Policies, Procedures and Guidelines. Retrieved from https://www.bced.gov.bc.ca/specialed/ppandg.htm

Calhoun, A., \& Daniels, G. (2008). Accountability in school responses to harmful incidents. Journal of School Violence, 7(4), 21-47. doi:10.1080/15388220801973839

Carroll, M. (2008). Educating expelled students after No Child Left Behind: An incentive structure that discourages alternative education and reinstatement. UCLA Law Review, 55, 1909-1969.

Christenson, S. L., Sinclair, M. F., Lehr, C. A., \& Godber, Y. (2001). Promoting successful school completion: Critical conceptual and methodological guidelines. School Psychology Quarterly, 16, 468-484.

Christenson, S. L., \& Thurlow, M. L. (2004). School dropouts: Prevention considerations, interventions, and challenges. Current Directions in Psychological Science, 13(1), 36-39.

Clarke, G., Boorman, G., \& Nind, M. (2011). "If they don’t listen I shout, and when I shout they listen": Hearing the voices of girls with behavioural, emotional and social difficulties. British Educational Research Journal, 37(5), 765-780. doi:10.1080/01411926.2010.492850

Cohen, J. S., \& Smerdon, B. A. (2009). Tightening the dropout tourniquet: Easing the transition from middle to high school. Preventing School Failure: Alternative Education for Children and Youth, 53(3), 177-184.

Coker, J. K., \& Borders, L. D. (2001). An analysis of environmental and social factors affecting adolescent problem drinking. Journal of Counseling \& Development, 79(2), 200-208.

Cook, C. R., Gresham, F. M., Kern, L., Barreras, R. B., Thornton, S., \& Crews, D. S. (2008). Social skills training for secondary students with emotional and/or behavioral disorders: A review and analysis of the meta-analytic literature. Journal of Emotional and Behavioral Disorders, 16(3), 131-144. doi:10.1177/1063426608314541

Cook-Sather, A. (2006). Sound, presence, and power: Student voice in educational research and reform. Curriculum Inquiry, 36(4), 359-390.

Cornell, D., \& Gregory, A. (2008). Virginia high school safety study: Descriptive report of survey results from ninth grade students and teachers. Currie School of Education, VA: University of Virginia. Retrieved from http://curry.virginia.edu/uploads/resourceLibrary/vhss-ninth-grade-survey-report-7-1308.pdf 
International Journal of Child, Youth and Family Studies (2016) 7(3/4): 381-403

Cox, S. M. (1999). An assessment of an alternative education program for at-risk delinquent youth. Journal of Research in Crime and Delinquency, 36(3), 323-336. doi:10.1177/0022427899036003004

Curran Neild, R., Stoner-Eby, S., \& Furstenberg, F. (2008). Connecting entrance and departure: The transition to ninth grade and high school dropout. Education and Urban Society, 40(5), 543-569. doi:10.1177/0013124508316438

D’Angelo, F., \& Zemanick, R. (2009). The Twilight Academy: An alternative education program that works. Preventing School Failure: Alternative Education for Children and Youth, 53(4), 211-218. doi:10.3200/PSFL.53.4.211-218

De La Ossa, P. (2005). “Hear my voice:” Alternative high school students’ perceptions and implications for school change. American Secondary Education, 34(1), 24-39.

Desbiens, N., \& Royer, E. (2003). Peer groups and behaviour problems: A study of school-based intervention for children with EBD. Emotional and Behavioural Difficulties, 8(2), 120-139. doi:10.1080/13632750300507012

Dinkes, R., Cataldi, E. F., Kena, G., Baum, K., \& Snyder, T. D. (2006). Indicators of school crime and safety: 2006 (NCES 2007-003/NCJ 214262). Washington, DC: U.S. Government Printing Office.

Erickson, M., Stage, S., \& Nelson, J. (2006). Naturalistic study of the behavior of students with EBD referred for functional behavioral assessment. Journal of Emotional and Behavioral Disorders, 14(1), 31-40. doi:10.1177/10634266060140010301

Fallis, R. K., \& Opotow, S. (2003). Are students failing school or are schools failing students? Class cutting in high school. Journal of Social Issues, 59(1), 103-119.

Fan, W., Williams, C. M., \& Corkin, D. M. (2011). A multilevel analysis of student perceptions of school climate: The effect of social and academic risk factors. Psychology in the Schools, 48(6), 632-647. doi:10.1002/pits.20579

Fantuzzo, J., McWayne, C., \& Bulotsky, R. (2003). Forging strategic partnerships to advance mental health science and practice for vulnerable children. School Psychology Review, 32(1), 17-37.

Farkas, M. S., Simonsen, B., Migdole, S., Donovan, M. E., Clemens, K., \& Cicchese, V. (2012). Schoolwide positive behavior support in an alternative school setting: An evaluation of fidelity, outcomes, and social validity of Tier 1 implementation. Journal of Emotional and Behavioral Disorders, 20(4), 275-288. doi:10.1177/1063426610389615 
International Journal of Child, Youth and Family Studies (2016) 7(3/4): 381-403

Fenning, P. A., Pulaski, S., Gomez, M., Morello, M., Maciel, L., Maroney, E., ... \& Morello, T. (2012). Call to action: A critical need for designing alternatives to suspension and expulsion. Journal of School Violence, 11(2), 105-117. doi:10.1080/15388220.2011.646643

Fielding, M. (2001). Students as radical agents of change. Journal of Educational Change, 2, 123-141.

Gregory, A., \& Cornell, D. (2009). “Tolerating” adolescent needs: Moving beyond zero tolerance policies in high school. Theory Into Practice, 48(2), 106-113. doi:10.1080/00405840902776327

Gregory, A., \& Weinstein, R. S. (2008). The discipline gap and African Americans: Defiance or cooperation in the high school classroom. Journal of School Psychology, 46(4), 455-475. doi:10.1016/j.jsp.2007.09.001

Gresham, F. (2000). Assessment of social skills in students with emotional and behavioral disorders. Assessment for Effective Intervention, 26(1), 51-58. doi:10.1177/073724770002600107

Griffith, J. (1999). The school leadership/school climate relation: Identification of school configurations associated with change in principals. Educational Administration Quarterly, 35, 267-291.

Hackett, L., Theodosiou, L., Bond, C., Blackburn, C., Spicer, F., \& Lever, R. (2010). Mental health needs in schools for emotional, behavioural and social difficulties. British Journal of Special Education, 37(3), 148-155. doi:10.1111/j.1467-8578.2010.00451.x

Haggman-Laitila, A. (1999). The authenticity and ethics of phenomenological research: How to overcome the researcher's own views. Nursing Ethics, 6, 12-22.

Hall, T. E., Meyer, A., \& Rose, D. H. (2012). Universal design for learning in the classroom: Practical applications. New York, NY: Guilford Press.

Haughey, A. (2009). Pupils disengaged from school: Evaluation of an alternative vocational education programme. Education and Child Psychology, 26, 52-59.

Hemphill, S. A., Plenty, S. M., Herrenkohl, T. I., Toumbourou, J. W., \& Catalano, R. F. (2014). Student and school factors associated with school suspension: A multilevel analysis of students in Victoria, Australia and Washington State, United States. Children and Youth Services Review, 36, 187-194. doi:10.1016/j.childyouth.2013.11.022

Janosz, M., Archambault, I., Morizot, J., \& Pagani, L. S. (2008). School engagement trajectories and their differential predictive relations to dropout. Journal of Social Issues, 64(1), 21-40. 
International Journal of Child, Youth and Family Studies (2016) 7(3/4): 381-403

Joe, S., Joe, E., \& Rowley, L. L. (2009). Consequences of physical health and mental illness risks for academic achievement in grades K-12. Review of Research in Education, 33(1), 283-309. doi:10.3102/0091732X08327355

Kauffman, J. M. (2001). Characteristics of emotional and behavioral disorders of children and youth. Upper Saddle River, NJ: Merrill Prentice-Hall.

Kauffman, J. M., \& Landrum, T. J. (2006). Children and youth with emotional and behavioral disorders: A history of their education. Austin, TX: Pro-Ed.

Knis-Matthews, L., Bokara, J., DeMeo, L., Lepore, N., \& Mavus, L. (2007). The meaning of higher education for people diagnosed with a mental illness: Four students share their experiences. Psychiatric Rehabilitation Journal, 31(2), 107-114.

doi:10.2975/31.2.2007.107.114

Kohn, A. (2004). Safety from the inside out: Rethinking traditional approaches. Educational Horizons, 83, 33-41.

Kuperminc, G. P., Leadbeater, B. J., \& Blatt, S. J. (2001). School social climate and individual differences in vulnerability to psychopathology among middle school students. Journal of School Psychology, 39(2), 141-159.

Kvale, S. (2007). Doing interviews. London, UK: SAGE Publications.

Lane, K. L., Wehby, J., \& Barton-Arwood, S. M. (2005). Students with and at risk for emotional and behavioral disorders: Meeting their social and academic needs. Preventing School Failure: Alternative Education for Children and Youth, 49(2), 6-9. doi:10.3200/PSFL.49.2.6-9

Lehr, C. A., Tan, C. S., \& Ysseldyke, J. (2009). Alternative schools: A synthesis of state-level policy and research. Remedial and Special Education, 30(1), 19-32. doi:10.1177/0741932508315645

Levin, B. (2000). Putting students at the centre in education reform. Journal of Educational Change, 1(2), 155-172.

Lincoln, Y. S., \& Guba, E. G. (1985). Naturalistic inquiry. Beverly Hills, CA: SAGE Publications.

Linnenbrink, E. A., \& Pintrich, P. R. (2003). The role of self-efficacy beliefs in student engagement and learning in the classroom. Reading and Writing Quarterly: Overcoming Learning Difficulties, 19(2), 119-137. doi:10.1080/10573560308223 
International Journal of Child, Youth and Family Studies (2016) 7(3/4): 381-403

MacLure, M., Jones, L., Holmes, R., \& MacRae, C. (2012). Becoming a problem: Behaviour and reputation in the early years classroom. British Educational Research Journal, 38(3), 447471. doi:10.1080/01411926.2011.552709

McCluskey, G. (2014). 'Youth is present only when its presence is a problem': Voices of young people on discipline in school. Children \& Society, 28(2), 93-103. doi:10.1111/j.1099$\underline{0860.2012 .00450 . x}$

McConnell-Henry, T., Chapman, Y., \& Francis, K. (2011). Member checking and Heideggerian phenomenology: A redundant component. Nurse Researcher, 18(2), 28-37. doi:10.7748/nr2011.01.18.2.28.c8282

Merrell, K. W., \& Walker, H. M. (2004). Deconstructing a definition: Social maladjustment versus emotional disturbance and moving the EBD field forward. Psychology in the Schools, 41(8), 899-910. doi:10.1002/pits.20046

Mitra, D. L. (2003). Student voice in school reform: Reframing student-teacher relationships. McGill Journal of Education, 38, 289-304.

Morone, J. A., Kilbreth, E. H., \& Langwell, K. M. (2001). Back to school: A health care strategy for youth. Health Affairs, 20(1), 122-136. doi:10.1377/hlthaff.20.1.122

Mottaz, C. (2002). Breaking the cycle of failure: How to build and maintain quality alternative schools. Lanham, MD: Scarecrow Press.

Moustakas, C. (1994). Phenomenological research methods. Thousand Oaks, CA: SAGE Publications.

Nakkula, M. J., \& Toshalis, E. (2006). Understanding youth: Adolescent development for educators. Cambridge, MA: Harvard Education Press.

Oeseburg, B., Jansen, D. E. M. C., Dijkstra, G. J., Groothoff, J. W., \& Reijneveld, S. A. (2010). Prevalence of chronic diseases in adolescents with intellectual disability. Research in Developmental Disabilities: A Multidisciplinary Journal, 31(3), 698-704.

Olympia, D., Farley, M., Christiansen, E., Pettersson, H., Jenson, W., \& Clark, E. (2004). Social maladjustment and students with behavioral and emotional disorders: Revisiting basic assumptions and assessment issues. Psychology in the Schools, 41(8), 835-847. doi:10.1002/pits.20040

Osler, A. (2006). Excluded girls: Interpersonal, institutional and structural violence in schooling. Gender and Education, 18, 571-589.

Patton, M. Q. (2002). Qualitative research \& evaluation methods. Thousand Oaks, CA: SAGE Publications. 
International Journal of Child, Youth and Family Studies (2016) 7(3/4): 381-403

Phillips, R. S. (2013). Toward authentic student-centered practices: Voices of alternative school students. Education and Urban Society, 45(6), 668-699. doi:10.1177/0013124511424107

Pirrie, A., Macleod, G., Cullen, M. A., \& McCluskey, G. (2009). Where next for pupils excluded from special schools and pupil referral units? (Research Report No DCSF-RR163). Ayr, Scotland: Department for Children, Schools and Families, University of the West of Scotland.

Pirrie, A., Macleod, G., Cullen, M. A., \& McCluskey, G. (2011). What happens to pupils permanently excluded from special schools and pupil referral units in England? British Educational Research Journal, 37(3), 519-538. doi:10.1080/01411926.2010.481724

Prosser, J. (2011). Visual methodology: Toward a more seeing research. In N. K. Denzin \& Y. S. Lincoln (Eds.), The SAGE handbook of qualitative research ( $4^{\text {th }}$ ed., Ch. 9). Thousand Oaks, CA: SAGE Publications.

Quinn, M. M., \& Poirier, J. M. (2004). Linking prevention research with policy: Examining the costs and outcomes of the failure to prevent emotional and behavioral disorders. In R. B. Rutherford, M. M. Quinn, \& S. R. Mathur (Eds.), Handbook of research in emotional and behavioral disorders (pp. 78-97). New York, NY: Guilford Press.

Reid, R., Gonzalez, J., Nordness, P., Trout, A., \& Epstein, M. (2004). A meta-analysis of the academic status of students with emotional/behavioral disturbance. Journal of Special Education, 38(3), 130-143. doi:10.1177/00224669040380030101

Roeser, R. W., \& Eccles, J. S. (1998). Adolescents' perceptions of middle school: Relation to longitudinal changes in academic and psychological adjustment. Journal of Research on Adolescence, 8(1), 123-158. doi:10.1207/s15327795jra0801_6

Ross, C. E., \& Wu, C. (1995). The links between education and health. American Sociological Review, 60, 719-745.

Rumberger, R. W. (2011). Dropping out. Cambridge, MA: Harvard University Press.

Skiba, R. J. (2002). Special education and school discipline: A precarious balance. Behavioral Disorders, 27, 81-97.

Skiba, R. J., \& Knesting, K. (2001). Zero tolerance, zero evidence: An analysis of school disciplinary practice. New Directions in Youth Development, 92, 17-43.

Smith, J. A. (1996). Qualitative methodology: Analysing participants’ perspectives. Current Opinion in Psychiatry, 9(6), 417-421.

Smith, J. A., Flowers, P., \& Larkin, M. (2009). Interpretative phenomenological analysis: Theory, method and research. Los Angeles, CA: SAGE Publications. 
International Journal of Child, Youth and Family Studies (2016) 7(3/4): 381-403

Smith, J. A., \& Osborne, M. (2003). Interpretative phenomenological analysis. In J. A. Smith (Ed.), Qualitative psychology: A practical guide to research methods. Thousand Oaks, CA: SAGE Publications.

Snyder, T. D., \& Dillow, S. A. (2010). Digest of education statistics 2010. Washington, DC: National Center for Education Statistics, Institute of Education Sciences.

Stewart, E. B. (2007). Individual and school structural effects on African American high school students’ academic achievement. The High School Journal, 91(2), 16-34.

Streeter, C. L., Franklin, C., Kim, J. S., \& Tripodi, S. J. (2011). Concept mapping: An approach for evaluating a public alternative school program. Children \& Schools, 33(4), 197-214.

Tobin, T., \& Sprague, J. (2001). Alternative education strategies: Reducing violence in school and the community. Journal of Emotional and Behavioral Disorders, 8(3), 177-186.

Trout, A., Nordness, P., Pierce, C., \& Epstein, M. (2003). Research on the academic status of children with emotional and behavioral disorders: A review of the literature from 1961 to 2000. Journal of Emotional and Behavioral Disorders, 11(4), 198-210. doi:10.1177/10634266030110040201

Vann, M., Schubert, S. R., \& Rogers, D. (2001). The Big Bayou Association: An alternative education program for middle-school, at-risk juveniles. Preventing School Failure:

Alternative Education for Children and Youth, 45(1), 31-36. doi:10.1080/10459880109599813

Vieno, A., Perkins, D. D., Smith, T. M., \& Santinello, M. (2005). Democratic school climate and sense of community in school: A multilevel analysis. American Journal of Community Psychology, 36(3-4), 327-341. doi:10.1007/s10464-005-8629-8

Watson, S. L. (2011). Somebody's gotta fight for them: A disadvantaged and marginalized alternative school's learner-centered culture of learning. Urban Education, 46(6), 14961525. doi:10.1177/0042085911413148

Wisner, B. L., \& Norton, C. L. (2013). Capitalizing on behavioral and emotional strengths of alternative high school students through group counseling to promote mindfulness skills. Journal for Specialists in Group Work, 38(3), 207-224.

doi:10.1080/01933922.2013.803504 